\title{
Factors Influencing the Purchase Decision of Smartphone Users in Sultanate of Oman
}

\author{
Renjith Kumar. R $^{*} \quad$ Diana Fernandez ${ }^{2}$ \\ 1. Lecturer in Marketing, Business Studies Department, University of Technology and Applied Sciences, Nizwa, \\ Sultanate of Oman, P.O. Box 477, P.C. 611 \\ 2. Lecturer in Accounting, Business Studies Department, University of Technology and Applied Sciences, \\ Nizwa, Sultanate of Oman, P.O. Box 477, P.C. 611
}

\begin{abstract}
Smartphones have become the daily necessity among people. People always look for the new model of smartphones, and the trend of changing smartphones is still very strong. The purpose of this research is to study the factors affecting the purchase intention of smartphones in Sultanate of Oman. The study has chosen seven variables to study the relationship between brand name, price, product features, convenience, dependency, social influence and purchase intention. An online questionnaire was adopted to carry out the study. The content of the survey included demographic factors and questions based on each variable. A sample of 51 responses are collected. It is concluded that the purchase decision has no significant relation between gender and age. It is proved that purchase decision of smartphone by Omanis is influenced by price, product features and social influence. Brand name, convenience and dependency has no impact significant impact on the purchase decision.
\end{abstract}

Keywords: Brand name, Price, Product features, Convenience, Dependency, Social influence, Purchase intention. DOI: $10.7176 / \mathrm{JMCR} / 72-04$

Publication date:October $31^{\text {st }} 2020$

\section{Introduction}

The Sultanate of Oman is a very vibrant mobile market with over $177 \%$ penetration on mobile usage. There is active regulation and enforcement of the market regulations, and high levels of supervision of mobile and internet operators. Almost $92 \%$ owned a smartphone and there is widespread use of the latest smartphone handsets, and almost $82 \%$ of the respondents indicated they had intermediate level skills with mobile technologies (www.tra.gov.om, 2011). Oman is the fastest growing market for smartphones in the GCC region with 65 per cent users switching to these devices, according to Ashrf Fawakherji, Vice-President, Middle East, for Huawei (Gulf News, 2013). Oman has a strong young customer base and 4G is more acceptable to that age category. According to Hootsuit Digital 2020 Report, the total population in Oman is 5.04 million with $72.4 \%$ using mobile phones. Compared between December 2018 to December 2019, there was an increase of $22 \%$ usage in mobile phones. The percentage of active social media users accessing via mobile is $100 \%$. The percentage of Facebook users accessing via a mobile phone is $93.1 \%$. The share of web traffic originating from android device in December 2019 is $88.8 \%$ and from Apple IOS device is $11 \%$. The mobile network infrastructure index score is 70.49 out of 100 . The affordability of devices and services index score is 69.34 out of 100 . Consumer readiness to use index score is 61.14 out of 100 . The index score of availability of relevant content and services is 66.03 . According to the Mobile market vendor market share, Oman, between August 2019 to August 2020, Huawei holds 51.05\%, followed by Samsung 28.45\%, Apple 12.65\%, Xiaomi 2.66\%, Oppo 1.25\%, and Nokia holds $0.82 \%$ market share (Statcounter, Global Stats, 2020). Excluding persons living in institutional households, Communications are essentially based on mobile phones. Smart phones are used almost as often as basic ones, with almost $95 \%$ of households having one, revealing a recent acceleration of access to and use. The number of mobile telephones is closely correlated with household size. The use of mobile phones starts at an early age. Among adolescents (15-19 years), 91\% of males and $83 \%$ of female already own a mobile phone and it is quite homogeneous throughout the country and between the population groups (ICT Household and Individuals Survey, 2013).

\section{Literature Review}

2. 1 Purchase Intention

Purchase intention is a dependent variable in this research that may be affected by different independent variables. Chang and Wildt (1994) defined purchase intention as an advance plan to purchase certain good or service in future. Purchase intention can identify the possibility to purchase through the intensity of intention. If consumers think that the product value is low, then their purchase intention will be weak, and the possibility to purchase will also be lower. Ayodele and Ifeanyichukwu (2016) found that different consumers will have different requirements for smartphone based on the characteristics such as price, brand name, functions, quality. Consumers will search the relevant information of the different products, compare and evaluate them before making purchase decision. The product is valuable if it satisfies the consumers' needs and wants. The purchase intention will be stronger, and the possibility to purchase will also be higher. 


\subsection{Price}

According to Sata (2013), every product should be priced as a certain level of acceptance from consumers. When products are priced at a lower price range, the consumers will not have enough confidence to buy it because consumers believe that lower price means lower quality. Although the price is lower, they strongly believe that they will find the best value of the product they purchased (Suki, 2013b). But still, price is a critical factor for people for purchasing smartphones. According to Kotler and Armstrong (2010), price is the sum of money that consumers usually pay for acquiring and using any product. According to Suki (2013b), the price is a tool of exchange to obtain a product or service. When people perceived that the quality of smartphone has exceeded their expectation, they will find it is good value for their money. Mobile phones' price is an important factor that many consumers considered in choosing a mobile phone model (Karjaluoto et al., 2003). In particular, younger customers considers price besides the technological advancements while purchasing any mobile phone (Karjaluoto et al., 2005). Whether the consumer buy a mobile handset often significantly affected by its price (Chapman \& Wahlers, 1999; Munnukka, 2005; Uddin et al., 2015). Suki (2013) also argued that product price significantly affect young university students' smartphone choice and buying behavior. Many prior studies (e.g.Lay-Yee, KokSiew and Yin Fah, 2013; Suki, 2013; Falayi and Adedokun, 2014; Kaushal and Kumar, 2016; Lin et al., 2017) also suggest that price of the product have significant influence on intention to purchase the product.

\subsection{Brand Name}

Brand name is the most valuable asset of a company and is an exclusive name which indicates product to the market. Brand name is more than just names and symbols. It is also the element of relationship between company and consumers (Kotler \& Armstrong, 2010). Researchers have concluded that brand name and brand image act as the critical factors for adding value to the product (Yeh, Wang \& Yieh, 2016). Liu, C.J. and Liang (2013) suggested that brand positively affects behavioral outcomes, including purchase intention. Consumers prefer a widely accepted brand of smartphone as it reflects a unique status symbol that display information quickly. The effect of brand name towards smartphone shows that people trust the well-known brand for its quality, performance and believe that brand shows a person lifestyle and social status. The product's brand name influenced consumers' evaluation and subsequently affected their buying decision (Malviya, Singh Saluja, \& Singh Thakur, 2013). Also, Bojei, J. and Hoo (2012), opines that consumers prefer to buy branded products and services as brands offer quality assurance and generate choices as well as simplifying purchase decision. Thus, smartphone's brand name is positively related to purchase behavior.

\subsection{Product Features}

Product features can be defined as the attributes of a product that can satisfy consumers' preferences through having the product, using and applying the product (Kotler \& Armstrong, 2007). Different people choose different features of smartphones that can meet with their needs and desires. According to Oulasvirta et al. (2011), smartphones nowadays are being featured with wireless connectivity, a built-in web browser, application installation, full programmability, a file management system, multimedia presentation and capture, high-resolution displays, high storage and location as well as movement sensors. There are five design characteristics of mobile phone being preferred by consumers such as camera, color screen, voice activated dialing, internet browsing and wireless connectivity (Ling et al., 2006). College students prefer to purchase mobile phone due to its physical appearance, size and menu organization. According to Lay-Yee et al (2013), hardware is the surface of device that can be physically touched such as body of the smartphone, size, weight, color as well design. Hardware and software can be categorized as product features. According to Russell (2012), consumers in Malaysia mostly prefer Android consists of $41 \%$, followed by IOS with $18 \%$, RIM Blackberry and Windows recorded the same with $6 \%$. The users in the other countries such as Singapore, Australia, New Zealand, Thailand and Vietnam mostly use Android operating system. Based on previous done by Lay-Yee et al (2013), 31\% of users prefer software compare to hardware only $17.6 \%$. This indicates consumers will look more on software rather than hardware in the purchase of smartphone.

\subsection{Convenience}

When buying a mobile phone, most of the people feel comfortable in buying a phone which they can operate easily and with minimum effort (Park \& Chen, 2007; Dunlop \& Brewster, 2002). Ease of use represents the scope to which a system can be used with a minimum level of efforts by its user (Davis, 1989) and is associated with easy learning, unproblematic and convenient use, flexibility and less complexity (Davis, Bagozzi \& Warshaw, 1989). Consumers frequently asses a particular mobile phone brand's ease of use with convenience. Consumers are interested to buy a mobile phone which is easily available and involves less complexity in using (Uddin et al., 2015). Previous studies (e.g. Ting et al. 2011; Lay-Yee et al., 2013; Suki and Suki, 2013) also suggested that convenience and ease of use have significant impact in determining consumer's purchase intention. Convenience in Smartphone may refer to the ability to use the Smartphone at anytime and anywhere, without having to port the 
Smartphone in a fixed workstation (Ding et al., 2011). The use of applications (apps) in Smartphone has flourished businesses by having ability such as documenting expenses and processing credit cards anywhere (Ranson, 2009). Smartphone able to keep everything such as documents, photos, games and apps in one's pocket, (Anthony, 2012). A study by Liew (2012) also used convenient as one of the determinants to test the significant relationship with demand of Smartphone. Ding et al. (2011) and Suki and Suki (2013) found the significant relationship between convenience and university students' dependency on Smartphone with purchase behavior.

\subsection{Social Influence}

Consumer behavior is influenced by social factors, such as the consumer's small groups, family, and social roles and status (Kotler \& Armstrong, 2010). It will be affected by variety of people, such as relatives, family member or friend etc. and also by the media. Social influence related to an individual may affect another person to change their feelings, attitudes, and behavior. Social influence has a significant relationship of student's dependency on a smartphone (Ting et al., 2011). If smartphones make a good impression or the experience from the consumer or their friends, consumers will base on them and it will lead to positive word-of-mouth. Friends and family members are seen as social influence perceived to be important to consumers in promoting and encouraging greater dependence on smartphones (Suki, 2013a). Consumers may be susceptible to social influence by observation, perception or anticipation of decisions made by others in relation to smartphones (Suki, 2013a). The intention to buy a branded smartphone is based on a consumer's attitude towards the brand as well as the influence of social norms and other people's expectations (Wong, 2017).

\subsection{Dependency}

Dependency is the strong propensity for continuous high usage, being engaged and unwilling to be apart from it (Ding et al., 2011). The smartphone is not only a conventional phone for talking or messaging; people can use them for a range of reasons, including banking, emailing, documenting, playing games, sharing photos, and social networking. For the younger generation, online education or E-learning has grown popularity in countries such as Malaysia, China, South Korea and India. People have become much dependent on Smartphone by doing most of the jobs using a Smartphone. In the United States, with growing dependency toward Smartphone, more people interact with the Smartphone rather than human. People are so obsessed that company introduced thousands of apps to make their Smartphone usage experience better (Gibson, 2011). In Malaysia, people spend around 20 hours per week for online surfing, with the purpose of connecting to people, learning, leisure and online purchase. Smartphone and tablets have also become an important device in surfing the internet (Lisa, 2011). There is a positive relationship between university students' dependency and their future purchase behavior, and "high dependency on Smartphone tends to make evaluations based on their past experiences in determining future purchase behavior" (Ding et al., 2011, Suki and Suki, 2013).

\subsection{Conceptual Model}

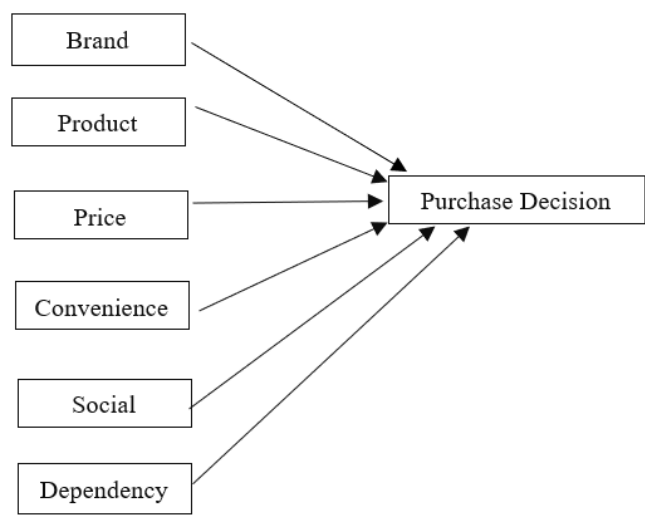

There are seven variables taken for the study. Purchase Decision is the dependent (outcome) variable. The factors that influence purchase decision are brand concern (Bhattacharya and Mitra, 2012, Khan et.al. 2015, LayYee et al. 2013, Mudondo, 2014), Product features (Mudondo, 2014), Price (Chow et al.2012, Chew 2012, Khan et.al. 2014, Lay-Yee et al. 2013), Convenience (Liew 2012, Lay-Yee et al. 2013, Ding et al. 2011, Mudondo 2014, and Suki 2013), Social influence (Wei and Lo 2006), and Dependency (Lay-Yee et al. 2013, Ding et al. 2011, and Suki 2013). These six variables are taken as the independent (predictor) variables.

\section{Statement of the problem}

Mohd Azam Osman et al. (2012), agreed that smartphone technology is changing peoples' behaviours especially young adults however surveys that have been carried out are still insufficient. There are lacks of understandings 
on the behavior and consumers' preferences towards the smartphone usage especially for young adults. According to Ericsson Consumer Lab (2013), 57 percent of university students use smartphone, 60 percent feel addicted to their phone, while 75 percent of them sleep next to their phones, 88 percent texted in class, 97 percent use them for social networking, and 40 percent utilized smartphone to study before test. In addition, the industry of mobile phone always showed drastic and tremendous changes or development in the telecommunication market. New models of smartphone are launched to the market from time to time in order to gain the competitive advantage in the market. The evolution of smartphone market has affected the users especially the young generation in term of motives and choice underlying the smartphone buying decision process.

3.1 Objectives of the study

1. To test the association between age, gender on purchase decision of smartphone brand.

2. To establish the correlation of independent variables on purchase decision of smartphones

3. To identify the impact of independent variables on purchase decision of smartphones.

\section{Research Methodology}

The study is conducted among the young Omanis in Nizwa, Sultanate of Oman. The period of study is from April 2020 to June 2020. The sampling frame includes mainly young Omanis as well as of all age groups residing in Nizwa. The sample size is 51. Primary data is collected with the help of a structured questionnaire which is shared through google form due to Corona pandemic. Hypothesis testing is done with the help of chi-square analysis. Regression analysis is conducted to find the impact of predictor (independent) variables on the dependent variable.

\section{Analysis and Discussions}

Table no.1 Demographic profile of mobile users

\begin{tabular}{|c|c|c|c|c|c|}
\hline \multicolumn{6}{|c|}{ Gender } \\
\hline & & Frequency & Percent & Valid Percent & Cumulative Percent \\
\hline \multirow[t]{3}{*}{ Valid } & Male & 8 & 15.7 & 15.7 & 15.7 \\
\hline & Female & 43 & 84.3 & 84.3 & 100.0 \\
\hline & Total & 51 & 100.0 & 100.0 & \\
\hline \multicolumn{6}{|c|}{ Age (in years) } \\
\hline & & Frequency & Percent & Valid Percent & Cumulative Percent \\
\hline \multirow[t]{5}{*}{ Valid } & $<20$ & 1 & 2.0 & 2.0 & 2.0 \\
\hline & $20-30$ & 40 & 78.4 & 78.4 & 80.4 \\
\hline & $>30-40$ & 7 & 13.7 & 13.7 & 94.1 \\
\hline & $>40-50$ & 3 & 5.9 & 5.9 & 100.0 \\
\hline & Total & 51 & 100.0 & 100.0 & \\
\hline \multicolumn{6}{|c|}{ Brand } \\
\hline & & Frequency & Percent & Valid Percent & Cumulative Percent \\
\hline \multirow[t]{7}{*}{ Valid } & Apple & 27 & 52.9 & 52.9 & 52.9 \\
\hline & HTC & 1 & 2.0 & 2.0 & 54.9 \\
\hline & Huawei & 14 & 27.5 & 27.5 & 82.4 \\
\hline & Lenovo & 1 & 2.0 & 2.0 & 84.3 \\
\hline & Nokia & 1 & 2.0 & 2.0 & 86.3 \\
\hline & Samsung & 7 & 13.7 & 13.7 & 100.0 \\
\hline & Total & 51 & 100.0 & 100.0 & \\
\hline
\end{tabular}

It is clear from table no. 1 that $84.3 \%$ of the respondents are females and $15.7 \%$ of the responses are from males. $78.4 \%$ of the mobile users are in the age group between $20-30$ years. Nearly $14 \%$ of the responses are from the age group of 30 to 40 years and $6 \%$ of them are between 40 and 50 years. The brand share of mobile shows that $53 \%$ of the users are Apple brand owners. $27.5 \%$ of the users use Huawei brand and only $13.7 \%$ of the people use Samsung. Remaining brands own a market share of $2 \%$ respectively. To determine whether there is any association between gender and mobile brand, the following hypothesis is proposed and tested.

Ho: There is no significant relationship between gender and brand of smart phone used.

H1: There is a significant relationship between gender and brand of smart phone used 


\begin{tabular}{|c|c|c|c|c|c|c|c|c|c|}
\hline \multicolumn{10}{|c|}{ Table no. 2 Gender and Brand of smart phone } \\
\hline & & & \multicolumn{6}{|c|}{$\begin{array}{ll}\text { Brand } \\
\end{array}$} & \multirow[t]{2}{*}{ Total } \\
\hline & & & Apple & HTC & Huawei & Lenovo & Nokia & Samsung & \\
\hline \multirow[t]{4}{*}{ Gender } & \multirow[t]{2}{*}{ Male } & Count & 5 & 0 & 2 & 0 & 0 & 1 & 8 \\
\hline & & Expected Count & 4.2 & .2 & 2.2 & .2 & .2 & 1.1 & 8.0 \\
\hline & \multirow[t]{2}{*}{ Female } & Count & 22 & 1 & 12 & 1 & 1 & 6 & 43 \\
\hline & & Expected Count & 22.8 & .8 & 11.8 & .8 & .8 & 5.9 & 43.0 \\
\hline \multirow[t]{2}{*}{ Total } & & Count & 27 & 1 & 14 & 1 & 1 & 7 & 51 \\
\hline & & Expected Count & 27.0 & 1.0 & 14.0 & 1.0 & 1.0 & 7.0 & 51.0 \\
\hline
\end{tabular}

There is not much difference found between the observed and the expected counts of gender compared with the brand owned.

\begin{tabular}{|l|c|c|c|}
\hline \multicolumn{4}{|c|}{ Table no.3 Chi-Square Tests } \\
\hline & Value & df & Asymp. Sig. (2-sided) \\
\hline Pearson Chi-Square & $.753^{\mathrm{a}}$ & 5 & .980 \\
\hline Likelihood Ratio & 1.212 & 5 & .944 \\
\hline N of Valid Cases & 51 & & \\
\hline a. 9 cells (75.0\%) have expected count less than 5. The minimum expected count is .16. \\
\hline
\end{tabular}

The Chi-square test carried out on the data is insignificant at 0.05 level $(\mathrm{p}>0.05)$ of significance. The Chisquare value is 0.753 at $\mathrm{df}=5$ and therefore it is concluded that there is no significant difference in the representation of gender across the mobile brands used. The Phi value is 0.122 with a significance of 0.980 . Cramer's value is also 0.122 that shows there is a weak relation between gender and brand used with a significance value of 0.980 which is greater than 0.05 . Hence it is concluded that there is no significant relationship between gender and brand of smart phone.

\begin{tabular}{|c|c|c|c|}
\hline \multicolumn{4}{|c|}{ Table no. 4 Symmetric Measures } \\
\hline & & Value & Approx. Sig. \\
\hline \multirow[t]{2}{*}{ Nominal by Nominal } & Phi & .122 & .980 \\
\hline & Cramer's V & .122 & .980 \\
\hline \multicolumn{2}{|l|}{$\mathrm{N}$ of Valid Cases } & 51 & \\
\hline
\end{tabular}

To determine whether there is any association between age group and mobile brand, the following hypothesis is proposed and tested.

Ho: There is no significant relationship between age group and brand of smart phone used.

H1: There is a significant relationship between age group and brand of smart phone used

\begin{tabular}{|c|c|c|c|c|c|c|c|c|c|}
\hline \multicolumn{10}{|c|}{ Table no. 5 Age and Brand of smart phone } \\
\hline & & & \multicolumn{6}{|c|}{ Brand } & \multirow[t]{2}{*}{ Total } \\
\hline & & & Apple & HTC & Huawei & Lenovo & Nokia & Samsung & \\
\hline \multirow[t]{8}{*}{ Age } & \multirow[t]{2}{*}{$<20$} & Count & 1 & 0 & 0 & 0 & 0 & 0 & 1 \\
\hline & & Expected Count & .5 & .0 & .3 & .0 & .0 & .1 & 1.0 \\
\hline & \multirow[t]{2}{*}{$20-30$} & Count & 23 & 1 & 10 & 1 & 0 & 5 & 40 \\
\hline & & Expected Count & 21.2 & .8 & 11.0 & .8 & .8 & 5.5 & 40.0 \\
\hline & \multirow[t]{2}{*}{$>30-40$} & Count & 1 & 0 & 3 & 0 & 1 & 2 & 7 \\
\hline & & Expected Count & 3.7 & .1 & 1.9 & .1 & .1 & 1.0 & 7.0 \\
\hline & \multirow[t]{2}{*}{$>40-50$} & Count & 2 & 0 & 1 & 0 & 0 & 0 & 3 \\
\hline & & Expected Count & 1.6 & .1 & .8 & .1 & .1 & .4 & 3.0 \\
\hline \multirow[t]{2}{*}{ Total } & & Count & 27 & 1 & 14 & 1 & 1 & 7 & 51 \\
\hline & & Expected Count & 27.0 & 1.0 & 14.0 & 1.0 & 1.0 & 7.0 & 51.0 \\
\hline
\end{tabular}

There is not much difference found between the observed and the expected counts of gender compared with the brand use.

\begin{tabular}{|c|c|c|c|}
\hline \multicolumn{5}{|c|}{ Table no. 6 Chi-Square Tests } \\
\hline & Value & df & Asymp. Sig. (2-sided) \\
\hline Pearson Chi-Square & $12.215^{\mathrm{a}}$ & 15 & .663 \\
\hline Likelihood Ratio & 11.506 & 15 & .716 \\
\hline N of Valid Cases & 51 & & \\
\hline a. 21 cells (87.5\%) have expected count less than 5. The minimum expected count is .02. \\
\hline
\end{tabular}




\begin{tabular}{|c|c|c|c|}
\hline \multicolumn{4}{|c|}{ Table no. 7 Symmetric Measures } \\
\hline & & Value & Approx. Sig. \\
\hline \multirow[t]{2}{*}{ Nominal by Nominal } & Phi & .489 & .663 \\
\hline & Cramer's V & .283 & .663 \\
\hline \multicolumn{2}{|c|}{$\mathrm{N}$ of Valid Cases } & 51 & \\
\hline
\end{tabular}

The Chi-square test carried out on the data is insignificant at 0.05 level $(\mathrm{p}>0.05)$ of significance. The Chisquare value is 0.663 at $\mathrm{df}=15$ and therefore it is concluded that there is no significant difference in the representation of age group across the mobile brands used. The Phi value is 0.489 with a significance of 0.663 . Cramer's value is 0.283 that shows there is a weak relation between age group and brand used with a significance value of 0.663 which is greater than 0.05 . Hence it is concluded that there is no significant relationship between age and brand of smart phone.

\begin{tabular}{|c|c|}
\hline \multicolumn{2}{|c|}{ Table no.8 Reliability Statistics } \\
\hline Cronbach's Alpha & N of Items \\
\hline .899 & 9 \\
\hline
\end{tabular}

Cronbach's alpha coefficient is the most frequently used to test the internal reliability of the items used in the study. Cronbach's alpha reliability coefficient normally ranges between 0 and 1 . If the value of Cronbach's alpha coefficient closer to 1.0, it means that the greater the internal consistency of the items in the scale. The obtained Cronbach's alpha value with 0.899 which is greater than 0.6. This indicates that all questions for the independent and dependent variables are standardized and can be accepted as the rule of thumb about Cronbach's alpha coefficient (Nunnally \& Bernstein, 1994).

5.1 Inferential analysis

This section presents the correlation analysis and regression analysis. In order to find the correlation and the impact of brand concern, price, product features, convenience, dependency and social influence on purchase decision, the mean values of the statements are taken into analysis.

\begin{tabular}{|l|c|c|c|}
\hline \multicolumn{4}{|c|}{ Table no. 9 Descriptive Statistics } \\
\hline & Mean & Std. Deviation & $\mathrm{N}$ \\
\hline Purchase Decision & 3.4678 & .81320 & 51 \\
\hline Brand concern & 3.5238 & .78541 & 51 \\
\hline Price & 3.5137 & .75499 & 51 \\
\hline Product Features & 4.0308 & .81931 & 51 \\
\hline Convenience & 3.9471 & .79733 & 51 \\
\hline Dependency & 3.8922 & .75116 & 51 \\
\hline Social influence & 2.9765 & .91446 & 51 \\
\hline
\end{tabular}

Table no. 9 shows the descriptive analysis of brand concern, price, product features, convenience, dependency and social influence (independent variables) and purchase decision (dependent variable). The mean value of dependent variable, purchase decision is 3.46 with a standard deviation of 0.81 . The mean value of social influence is lowest with 2.97and a standard deviation of 0.91. A low standard deviation indicates that the data points tend to close to the mean. A high standard deviation indicates that the data points are spread across a wider range of values. The mean is high for the independent factor 'product features' (4.03) but the standard deviation is less for the independent factor 'dependency' $(0.751)$. Therefore, dependency is a consistent factor that affects purchase decision, as the spread around the mean is less.

\begin{tabular}{|l|l|c|c|c|c|c|c|c|}
\hline \multicolumn{2}{|c|}{ Table no.10 Correlations } \\
\hline & $\begin{array}{c}\text { Purchase } \\
\text { Decision }\end{array}$ & $\begin{array}{c}\text { Brand } \\
\text { concern }\end{array}$ & Price & $\begin{array}{c}\text { Product } \\
\text { Features }\end{array}$ & Convenience & Dependency & $\begin{array}{c}\text { Social } \\
\text { influence }\end{array}$ \\
\hline $\begin{array}{l}\text { Pearson } \\
\text { Correlation }\end{array}$ & $\begin{array}{l}\text { Purchase } \\
\text { Decision }\end{array}$ & 1.000 & .687 & .803 & .576 & .598 & .554 & .736 \\
\cline { 2 - 10 } & Brand concern & .687 & 1.000 & .811 & .615 & .575 & .537 & .508 \\
\cline { 2 - 10 } & Price & .803 & .811 & 1.000 & .576 & .707 & .653 & .702 \\
\cline { 2 - 10 } & Product Features & .576 & .615 & .576 & 1.000 & .764 & .805 & .318 \\
\cline { 2 - 10 } & Convenience & .598 & .575 & .707 & .764 & 1.000 & .788 & .546 \\
\cline { 2 - 10 } & Dependency & .554 & .537 & .653 & .805 & .788 & 1.000 & .513 \\
\cline { 2 - 9 } & Social influence & .736 & .508 & .702 & .318 & .546 & .513 & 1.000 \\
\hline
\end{tabular}

Based on the results in table no.10, there is a positive relationship between brand and purchase decision $(\mathrm{R}=$ 0.687). A positive relationship means that when brand awareness increases, purchase decision also increases. The $\mathrm{r}$-value is 0.687 , which means there is a moderate uphill (positive) linear relationship between brand awareness and purchase decision. There is a positively high correlation between price $(0.803)$ and purchase decision. The relationship between social influence (0.736) and purchase decision is fairly strong positive. There is a moderate 
positive correlation between product features (0.576) and purchase decision, between convenience (0.598) and purchase decision, between dependency (0.554) and purchase decision.

\begin{tabular}{|l|c|c|c|c|c|}
\hline \multicolumn{5}{|c|}{ Table no. 11 Model Summary } \\
\hline Model & $\mathrm{R}$ & R Square & Adjusted R Square & $\begin{array}{c}\text { Std. Error of the } \\
\text { Estimate }\end{array}$ & Durbin-Watson \\
\hline 1 & $.876^{\mathrm{a}}$ & .768 & .736 & .41768 & 2.429 \\
\hline
\end{tabular}

a. Predictors: (Constant), Social influence, Product Features, Brand concern, Convenience, Dependency, Price

b. Dependent Variable: Purchase Decision

The model Summary table no.11 provides the $R, R^{2}$, adjusted $R^{2}$, and the standard error of the estimate, which can be used to determine how well a regression model fits the data. The $\mathrm{R}$ value represents multiple correlation coefficient and it is considered as one measure of the quality of the prediction of the dependent variable. A value of 0.876 indicated a good level of prediction. The "R Square" column represents the $R^{2}$ value (also called the coefficient of determination), which is the proportion of variance in the dependent variable that can be explained by the independent variables. Thus $76.8 \%$ of these predictors (social influence, product features, brand, convenience, dependence and price) contributes to purchase decision of smart phones. Remaining $33.2 \%$ contributes to other factors that influence the purchase decision. This means that there are other extra independent variables that were not put into consideration in this study that is significant in explaining the variation in purchase decision. The adjusted $R^{2}(0.736)$ gives an idea how well the model generalizes that the value is close to $R^{2}(0.768)$. There is a difference of 0.032 . This shrinkage means that if the model were derived from the population rather than from a sample, it would account for $3.2 \%$ less variance in the outcome. The size of Durbin-Watson statistic depends upon the number of predictors in the model and the number of observations. The test statistic can vary between 0 and 4 (Durbin and Watson, 1951). But Field (2009) suggested that values less than 1 and greater than 3 are definitely cause for concern. In this case the Durbin Watson value is 2.429 which is an acceptable test statistic.

\begin{tabular}{|l|c|c|c|c|c|}
\hline \multicolumn{7}{|c|}{ Table no. 12 ANOVA } \\
\hline Model & Sum of Squares & Df & Mean Square & F & Sig. \\
\hline Regression & 25.388 & 6 & 4.231 & 24.254 & $.000^{\mathrm{b}}$ \\
\hline Residual & 7.676 & 44 & .174 & & \\
\hline Total & 33.064 & 50 & & & \\
\hline a. Dependent Variable: Purchase Decision \\
\hline
\end{tabular}

The ANOVA test was performed to identify the statistical significance of the regression model on whether it is a good descriptor for the relationship between the predictor variables (social influence, product features, brand, convenience, dependence and price) and the dependent variable (purchase decision). The $F$-ratio in the ANOVA table tests whether the overall regression model is a good fit for the data. The table no.12 shows that the independent variables statistically significantly predict the dependent variable, $F(6,44)=24.254, p<.05$ (i.e., the regression model is a good fit of the data). This means that the independent variables (social influence, product features, brand, convenience, dependence and price) are significant in explaining the variation in the dependent variable (purchase decision). The ANOVA table, proves that the overall correlation 0.876 is significant. Hence the model is significant.

\begin{tabular}{|c|c|c|c|c|c|c|c|c|}
\hline \multirow[b]{3}{*}{ Model } & \multicolumn{7}{|c|}{ Table no.13 Coefficients } & \\
\hline & \multicolumn{2}{|c|}{$\begin{array}{l}\text { Unstandardized } \\
\text { Coefficients }\end{array}$} & \multirow{2}{*}{$\begin{array}{c}\text { Standardized } \\
\text { Coefficients } \\
\text { Beta } \\
\end{array}$} & \multirow[b]{2}{*}{$\mathrm{T}$} & \multirow[b]{2}{*}{ Sig. } & \multicolumn{2}{|c|}{$\begin{array}{c}\text { Collinearity } \\
\text { Statistics }\end{array}$} & \\
\hline & B & $\begin{array}{l}\text { Std. } \\
\text { Error }\end{array}$ & & & & Tolerance & VIF & \\
\hline (Constant) & .232 & .338 & & .685 & .497 & & & \\
\hline Brand concern $(\mathrm{X} 1)$ & -.019 & .143 & -.019 & -.135 & .893 & .275 & 3.630 & Insignificant \\
\hline Price $(\mathrm{X} 2)$ & .536 & .181 & .498 & 2.960 & .005 & .187 & 5.361 & Significant \\
\hline $\begin{array}{ll}\begin{array}{l}\text { Product } \\
\text { (X3) }\end{array} & \text { Features } \\
\end{array}$ & .488 & .152 & .492 & 3.208 & .002 & .224 & 4.459 & Significant \\
\hline Convenience (X4) & -.165 & .145 & -.162 & -1.141 & 260 & .263 & 3.805 & Insignificant \\
\hline Dependency (X5) & -.290 & .160 & -.268 & -1.811 & .077 & .241 & 4.142 & Insignificant \\
\hline $\begin{array}{l}\text { Social influence } \\
\text { (X6) }\end{array}$ & .414 & .097 & .465 & 4.265 & .000 & .444 & 2.253 & Significant \\
\hline
\end{tabular}

The coefficients in table no.13 helped to compare which of the six predictor variables (social influence, product features, brand, convenience, dependence and price) contribute the most to the variation of purchase decision. To make the comparison, the Beta standardized coefficients were used. The results indicate that Price ( $\beta$ 
$=0.498 ; p=0.005)$ is a significant predictor of purchase decision. Prior studies found that product price affect purchase intention of cellular phone (Md. Rakibul, 2019, Karjaluoto et al., 2005; Munnuka, 2005; Uddin et al., 2015). This study also confirmed that product price has significant influence on young Omanis' smart phone purchase.

The predictor Product features $(\beta=0.492 ; p=0.002)$ also influences the purchasing decision. This study confirmed that product features is significantly and positively related to purchase intention of smartphone. The result is consistent with the findings of the previous studies. Product features were positively related to purchase intention of smartphone (Ling et al., 2006; Lay-Yee, Kok-Siew, \& Yin-Fah, 2013). The study also found product features have significant influence on university students' cellular phone purchase intention. Chang and Wildt (2012) have mentioned that product value affected the purchase intention. Consumers measure value through collecting and compare the relevant data of the product. This result is consistent with some other previous research (e.g. Karjaluoto et al., 2005, Lay-Yee et al., 2013; Uddin et al., 2015; Rahim et al., 2016, Md. Rakibul, 2019, Anthony, 2019).

Another independent variable that influences the purchase decision of Omanis is Social influence $(\beta=0.465$; $p=0.000$ ). This study shows that social influence is significant and positively related to purchase intention of smartphone. It is consistent with the results of other studies (Anthony, 2019; Harun, Sulong and Bin; 2015; Lim, Han and Chan; 2013). Social influence was reported as significant factor by previous studies like - Qun, Howe, Thai, Wen and Kheng (2012); Ding et al. (2011); Suki and Suki, (2013); Malviya, Saluja \& Thakur, (2013); Anam (2014); Ibrahim, Subari, Kasim \& Mohammad (2013), which is supported by the present study. Lim et al. (2013) commented that social influence was found to be positively related to purchase intention of smartphone. This study also found that there was a significant and positive relationship between social influence and purchase intention of smartphone. Similar findings were reported in the study of social influence and purchase intention (Mohd Azam, 2012; Suki \& Suki, 2013; Lay-Yee et al., 2013). According to Ibrahim et al. (2013), social influence was found to be positively related to purchase intention of smartphone.

Brand concern $(\beta=-0.19 ; p=0.893)$ is not a significant predictor of purchase decision of smart phones. This is in support with Karen et al. (2013) who identified that there is no significant correlation between Brand Concern with Customer Purchase Decision. This is in contradiction with the results of Anthony (2019) where brand name significantly affects purchase intention. Another predictor is Convenience $(\beta=-0.162 ; p=0.260)$ which is not a significant factor of purchase intention. This result is supported by the findings of Md. Rakibul (2019) where convenience do not have an impact on purchase intention. But other studies (Park and Chen, 2007; Joo and Sang, 2013; Kim, Chun and Lee, 2014; Uddin et al., 2015) found that ease of use has significant influence on consumers' smartphone phone purchase intention. Dependency $(\beta=-0.268 ; p=0.77)$ is another insignificant predictor of purchase decision of smart phones. The study results are in contradiction with Kaushal and Rakesh, (2016); LayYee, Kok Siew \& Yin Fah, (2013) where dependency is a significant factor influencing purchase intention.

Thus it is statistically proved through the model that Price, Product features and Social influence have significant impact on purchase decision of smart phone users. Even though brand concern, convenience and dependency are positively correlated to dependent variable (purchase decision), they have insignificant impact on purchase decision.

Since the tolerance is more than 0.2 , there is no multicollinearity problem between the independent variables. To determine whether there is similarity between the independent variables in the model, it is necessary to do multicollinearity test. Multicollinearity test is done to avoid the partial effect of independent variables on the dependent variable. Good regression model should be free from correlation between the independent variables or there should be no multicollinearity. If the VIF (Variance Inflation Factor) value lies between 1 and 10, then there is no multicollinearity. If the VIF value is less than 1 or greater than 10 , then there is multicollinearity. Based on the Coefficients output (table no.13), Collinearity statistics, obtained VIF values of the predictor variables are between 1 and 10 . Hence it is concluded that there is no multicollinearity symptoms.

Therefore, the Regression equation is developed as follows:

$\mathrm{Y}=\mathrm{a}+\mathrm{bX}$

Where ' $\mathrm{Y}$ ' is the dependent variable purchase decision, $\mathrm{a}$ and $\mathrm{b}$ are constants.

The model equation based on the analysis is given below:

$\mathrm{Y}=0.232+0.536 \mathrm{X} 2+0.488 \mathrm{X} 3+0.414 \mathrm{X} 6$

where X2 represents Price, X3 Product features and X6 represents Social influence

Purchase Intention $=0.232$ (Price) +0.488 (Product features $)+0.414$ (Social influence)

Hence, it is concluded that the purchase decision of smartphones by young Omanis in Nizwa is influenced by price, product features and by society. Any change in these variables will directly affect the purchase decision of smartphone purchase in future.

\section{Findings of the study}

1. The data analysis reveal that the gender and age are insignificant in determining the brand choice of mobile 
phones among Omanis in Nizwa.

2. The study reveals that a moderate positive correlation exists between the dependent variable purchase decision and the predictor variables such as brand awareness, product features, convenience and dependency. The relationship between social influence and purchase decision is fairly strong positive relationship whereas there exists a high positive correlation between price and purchase decision.

3. Among the six predictor variables analyzed, three of them viz; price, product features and social influence have significant positive impact on the purchase intention of smartphones among Omanis. The other three variables such as brand, convenience and dependency are insignificant predictors of purchase decision. The findings show that these predictors contribute to $76.8 \%$ of the factors that influence the purchase decision of smart phones.

\subsection{Recommendations}

The results of the study will be helpful for smartphone manufacturers and marketers to devise appropriate strategic and operational plans that would contribute towards enhancing the sales.

Based on the background of the study the following recommendations are made:

1. The manufacturers may offer improved and innovative product features that would better appeal to young adults who form the major market share of smartphone industry. Innovative product features help to increase the level of dependency and in turn can positively affect the purchase decision.

2. Advertising using social media can easily promote brand awareness as it is widely accessed by customers particularly the youngsters. Brand awareness helps manufacturers of smartphones to stand out above competitors and generate more leads.

3. An attractive and appealing pricing strategy that best suits the current market conditions may be designed by companies. Providing attractive credit facilities, easy installment purchase schemes, offers etc. can improve accessibility.

\subsection{Conclusion}

The study concludes that the increase in the brand awareness, improvement in the product features, convenience in access and usage, level of dependency and the price changes positively affect the purchase decision of smartphones among Omani users. However, the study concludes that gender and age are insignificant in determining the brand choice of smart phones. It can be concluded that the other factors significant in explaining the variation in purchase decision that were not put into consideration in this study accounts to $33.2 \%$. The study provides scope for future researches to examine other predictor variables that influence the purchase decision.

\subsection{Limitations and Direction for future research}

The results of the study cannot be generalized to the entire population as the sample was collected from one area of Sultanate of Oman. The sample size was less due to the pandemic of Corona. The demographic variables taken for this study are gender and age. There are other influential predictors of purchase intention of smart phones that are to be included in future research. They are Compatibility (Anam, 2014; Qun et al. 2012), Relative advantage (Tidd, 2010), Social need (Mudondo, 2014; Tikkanan 2009), and Product sacrifice (Zeithamal, 1996; Sok, 2005). Future research could be done by examining the four more predictive variables affecting the purchase decision. Researchers could also focus on associating the relationship of income, education, life style and culture with the variables under study.

\section{References}

Anam, C. (2014). The Impact of Social Influence, Compatibility, and Price on Purchase Intension of Android Smart Phone. Unpublished thesis. Department: Management, Faculty Economics and Business Muhammadiyah University of Sukarta.

Anthony Tik-Tsuen Wong, (2019), A Study of Purchase Intention on Smartphones of Post 90s in Hong Kong, Asian Social Science; Vol. 15, No. 6; pp 78-87, Published by Canadian Center of Science and Education.

Anthony, S., 2012. There can only be one: Smartphone are the PCs of the future [Online]. Available from http://www.extremetech.com/computing/134868-there-can-only-be-one-Smartphones-are-the-pcsof-thefuture.

Ayodele, A. A., Ifeanyichukwu, C. (2016). Factors Influencing Smartphone Purchase Behavior Among Young Adults in Nigeria. International Journal of Recent Scientific Research, 7(9), 13248-13254.

Bhattacharya, Swaha \& Mitra, Sritama, 2012. "Consumer Behaviour And Impact Of Brand - A Study On South Zone Of Kolkata City," Voice of Research ,Working papers 2012-2-12,

Bojei, J., \& Hoo, W. C. (2012). Brand equity and current use as the new horizon for repurchase intention of smartphone. International Journal of Business and Society, 13(1), 33-48.

Chang, T. Z., \& Wildt, A. R. (1994). Price, Product information, and purchase intention: an empirical study. 
Journal of the Academy of Marketing Science, 22(1), 16-27. https://doi.org/10.1177/0092070394221002

Chapman, J. and Wahlers, R. (1999). A Revision and Empirical Test of the Extended Price-Perceived Quality Model. Journal of Marketing Theory and Practice, 7 (3), pp. 53-64.

Chew, J.Q., 2012. Exploring the factors affecting purchase intention of smartphone: A study of young adults in UTAR, Unpublished Degree Paper. Universiti Tunku Abdul Rahman, Perak Campus, Malaysia.

Chow M. M., Chen L. H. \& Wong P. W. (2012). Conceptual Paper: Factors Affecting the Demand of Smartphone among Young Adult. International Journal on Social Science Economics and Arts, 2 (2), 44-49.

Davis, F. D. (1989). Perceived usefulness, perceived ease of use, and user acceptance of information technology, MIS Quarterly, 13 (3), 319-340.

Davis, F. D., Bagozzi, R. P., \& Warshaw, P. R. (1989). User acceptance of computer technology: A comparison of two theoretical models, Management Science, 35(8), 982-1003.

Ding, H.T., F.L. Suet, S.P. Tanusina, G.L. Ca and C.K. Gay, 2011. Dependency on smartphone and the impact on purchase behaviour, Young consumers: Insight and Ideas for Responsible Marketers, 12(3): 193- 203

Dunlop, M. and Brewster, S. (2002). The Challenge of Mobile Devices for Human Computer Interaction. Personal and Ubiquitous Computing, 6 (4), pp. 235-236

Durbin, J. and Watson, G.S. (1951), "Testing for Serial Correlatión in Least Squares Regression - II", Biometrika, 38, pp 159-178.

Ericsson Consumer Lab. (2013). Smartphone usage experience: An Ericsson consumer insight summary report. Retrieved from http:/www.slideshare.net/EricssonSlides/ericsson-consumer-lab-smartphone-usageexperience-report.

Falayi, O. R., \& Adedokun, A. J. (2014). The demand for smartphones among students in university of Ibadan. Economics, 1(1), 30-34.

Field, A. (2009). Discovering Statistics Using SPSS, 3rd ed., SAGE Publications India Pvt Ltd.

Gibson, E., 2011. Smartphone dependency: A growing obsession with gadgets [Online]. Available from http://usatoday30.usatoday.com/news/health/medical/health/medical $/$ mentalhealth/story $/ 2011 / 07 / \mathrm{Sm}$ artphone-dependency-a-growing-obsession-to-gadgets/49661286/1.

Harun, A., Sulong, R., \& Bin, A. W. (2015). Smartphone Dependency and Its Impact on Purchase Behavior. Asian Social Science, 11(26), 196-211. https://doi.org/10.5539/ass.v11n26p196

Ibrahim, I.I., Subri, K.A., Mohamaed Kassim, K., and Mohamood, S.K. (2013). Antecedents stirring purchase intention of smartphone among adolescents in Perlis. International Journal of Academic Research in Business and Social Science, 3(13), 84-97.

Joo, J., \& Sang, Y. (2013). Exploring Koreans' smartphone usage: An integrated model of the technology acceptance model and uses and gratifications theory. Computers in Human Behavior, 29(6), 2512-2518.

Karen Lim Lay-Yee; Han Kok-Siew; Benjamin Chan Yin-Fah (2013), Factors Affecting Smartphone Purchase Decision Among Malaysian Generation Y, International Journal of Asian Social Science, 2013, 3(12): 24262440

Karjaluoto, Heikki; Karvonen, Jari; Kesti, Manne ; Koivumäki, Timo ; Manninen, Marjukka ; Pakola, Jukka ; Ristola, Annu; Salo, Jari. (2005). Factors Affecting Consumer Choice of Mobile Phones: Two Studies from Finland. Journal of Euromarketing. 14. 10.1300/J037v14n03_04.

Karjaluoto, Heikki ; Mattila, Minna ; Pento, Tapio. (2002). Factors underlying attitude formation towards online banking in Finland. International Journal of Bank Marketing. 20. 261-272. 10.1108/02652320210446724.

Kaushal S.K, Rakesh Kumar, (2016), Factors Affecting the Purchase Intension of Smartphone: A Study of Young Consumers in the City of Lucknow, Pacific Business Review International, Volume 8, Issue 12, pp 1-16.

Khan Nasreen, Syed Hamed Razavi Rahmani, Hong Yong Hoe \& Tan Booi Chen, (2015). Causal Relationships among Dimensions of Consumer-Based Brand Equity and Purchase Intention: Fashion Industry, International Journal of Business and Management; Vol. 10, No. 1; 2015, pp 172-181.

Kim, D., Chun, H., \& Lee, H. (2014). Determining the factors that influence college students' adoption of smartphones. Journal of the Association for Information Science and Technology, 5(3), 578-588.

Kotler, P., \& Armstrong, G. (2007). Principles of Marketing (12th ed.). Boston: Pearson Education.

Kotler, P., \& Armstrong, G. (2010). Principles of Marketing.(13 ${ }^{\text {th }}$ edition) Pearson Education.

Lay-Yee, K.L., Kok-Siew, H., and Yin-Fah, B.J. (2013). Factors affecting smartphone purchase decision among Malaysian Generation Y. International Journal of Asian Social Science, 3(12), 2426-2440.

Liew, T. S. (2012). Smartphone dependency and impact on consumer purchase behaviour of people in Kota Kinabalu, Unpublished Master Thesis, University Sabah Malaysia, Malaysia

Lim, L. Y. K., Han, K. S., \& Chan, B. Y. F. (2013). Factors Affecting Smartphone purchase decision among Malaysian generation Y. International Journal of Asian Social Science, 3(12), 2426-2440.

Lin, C.-Y., Chao, Y.-C., \& Tang, T.-W. (2017). Why not be "smarter"? Examining the factors that influence the behavioral intentions of non-smartphone users. Industrial Management \& Data Systems, 117(1), $32-49$.

Ling C., Hwang W. and Salvendy G. (2006). Diversified users' satisfaction with advanced mobile phone features, 
Universal Access in the Information Society, 5(2), 239-249.

Lisa, J.A., 2011. Nielsen: Malaysians spend 20 hours online per week [Online]. Available from http://www.themalaysianinsider.com/mobile/malaysia/article/nielsen-malaysians-spend-20-hoursonline-perweek/.

Liu, C. J., \& Liang, H. Y. (2013). The deep impression of smartphone brand on the customers' decision making. Procedia - Social and Behavioral Sciences, 109(8), 338-343. https://doi.org/10.1016/j.sbspro.2013.12.468

Malviya S., Saluja M. S., \& Thakur A.S. (2013). A Study on the Factors Influencing Consumer's Purchase Decision towards Smartphones in Indore, International Journal of Advance Research in Computer Science and Management Studies, Volume 1, Issue 6, pp 14-21.

Md. Rakibul Hafiz Khan Rakib (2019), Factors Influencing Purchase Intention of Cellular Phones Among the University Students in Bangladesh, European Journal of Business and Management, Vol.11, No.2, 2019, pp 92-101, DOI: 10.7176/EJBM

Mohd Azam Osman., Abdullah Zawawi Talib., Zainal Abidin Samusi., Tan Shiang Yen., \& Abdullah Sani Alwi. (2012). A study of the trend of smartphone and its usage behavior in Malaysia. International Journal on New Computer Architectures and Their Application (UNCAA), 2(1), 274-285.

Mudondo, C. D. (2014). Determinants of Generation-Y brand preferences in the mobile phone market in Southern Zimbabwe. Research Journal of Commerce, 2(5) pp 2-12.

Munnukka, J. (2005). Dynamics of Price Sensitivity among Mobile Service Customers. Journal of Product and Brand Management, Vol. 14 (1), pp. 65-73

Nunnally, J. C., \& Bernstein, I. H. (1994). Psychometric theory (3rd ed.). New York: McGraw- Hill.

Oulasvirta, A., Wahlstrom, M. and Ericsson K. A. (2011). What does it mean to be good at using mobile device? An investigation of three levels of experience and skill. International Journal of Human-Computer Studies, 69, 155-169.

Park, Y. and Chen, J. V. (2007). Acceptance and Adoption of the Innovative Use of Smartphone. Industrial Management and Data Systems, 107 (9), pp. 1349-1365.

Qun, C. J., Howe, L. J., Thai, L. C., Wen, L. W. and Kheng, W. T. (2012). Exploring the factors affecting purchase intension of Smartphone: A study of young adults in University Tunku Abdul Rahman, Perak Campus Malaysia (Unpublished Bachelor Thesis), University Tunku Abdul Rahman, Malaysia

Ranson, D., 2009. Smartphone apps fuel business [Online] Available from http://online.wsj.com/article/SB125071635069144197.html.

Russell, J., (2012). Android dominates Southeast Asia's smartphone market: Report [Online]. Available from http://thenextweb.com/asia/2012/09/04/android-southeast-asia-ericsson-report/

Sata, M. (2013). Factors Affecting Consumer Buying Behavior of Mobile Phone Devices. Mediterranean Journal of Social Sciences, 4(12), 103-112. https://doi.org/10.5901/mjss.2013.v4n12p103

Sok Channa (2005), Factors Affecting Consumer Perceived Value and Purchase Intention of Mobile Phone in Cambodia and Taiwan, International Master of Business Administration (IMBA) Program, National Cheng Kung University.

Suki, N. M. (2013a), Students' dependence on smart phones: The influence of social needs, social influences and $\begin{array}{lllll}\text { convenience. } & \text { Campus-Wide } & \text { Information } & \text { Systems, } & 30(2),\end{array}$ 134.https://doi.org/10.1108/10650741311306309.

Suki, N. M. (2013b). Students' demand for smartphones: Structural relationships of product features, brand name, product price and social influence. Campus-Wide Information Systems, 30(4), 236-248. https://doi.org/10.1108/CWIS-03-2013-0013.

Suki, N. M., \& Suki, N. M. (2013). Dependency on Smartphones: An Analysis of Structural Equation Modelling. Journal of Technology, 62(1), 49-55.

Sunil K Vaidya, Bureau Chief, Gulf News, 65\% Mobile Users in Oman move to smartphones, June 26, 2013.

Tidd, J (2010). From models to the management of diffusion. In Tidd, J (ed.) Gaining Momentum: Managing the Diffusion of Innovations. London: Imperial College Press.

Tikkanen, I. (2009) Maslow's hierarchy and pupils' suggestions for developing school meals. Nutrition and Food Science, 39(5) pp 534-43

Ting, D. H., Lim, S. F., Patanmacia, T. S., Low, C. G., \& Ker, G. C. (2011). Dependency on smartphone and the impact on purchase behavior. Young Consumers: Insight and Ideas for Responsible Marketers, 12(3), 193203. https://doi.org/10.1108/17473611111163250

Uddin, Md Reaz; Lopa, Nusrat; Md, Oheduzzaman. (2014). Factors Affecting Customers' Buying Decisions of Mobile Phone: A Study on Khulna City, Bangladesh. International Journal of Managing Value and Supply Chains. 5. 21-28. 10.5121/ijmvsc.2014.5203.

Uddin, M. A., Xu, H., \& Azim, M. T. (2015). Factors affecting mobile handset (MH) buying Decision: An empirical study. International Journal of Management and Business Research, 5 (3), 225-236.

Wei, R. and Lo, V. H. (2006). Staying connected while on the move: Cell phone use and social connectedness. 
New Media and Society, 8(1) pp 53-72.

Wong, A. T. T. (2017). Determinants Affecting Repurchasing Behaviors Towards Online Shopping in HongKong. Journal of Global Economics, Management and Business Research, 8(4), 193-203.

Yeh, C. H., Wang, Y. S., \& Yieh, K. (2016). Predicting smartphone brand loyalty: Customer value and consumerbrand identification perspectives. International Journal of Information Management, 36(3), 245-257. https://doi.org/10.1016/j.ijinfomgt.2015.11.013

Zeithmal, V.A., (1996). The behavioral consequences of service quality. Journal of Marketing, Vol.60 No.2, pp.31-46

\section{Websites}

https://datareportal.com/reports/digital-2020-oman., Digital 2020 Report, Hootsuite Report.

https://gs.statcounter.com/vendor-market-share/mobile/oman, Global Stats, 2020

http://www.itu.int/en/ITU-D/Statistics/Pages/publications/manual2014.aspx, ICT Households and Individuals 2013, survey on access to, and use of information and communication technology (ICT) by households and individuals in Oman 2014

www.tra.gov.om/newsite, 2011. Telecommunications Regulatory Authority (TRA) - http://www.tra.gov.om, Documents 467-11-2011. 